\title{
The impact of medical gymnastics on load on the lower limb after knee twisting, on the basis of selected tests
}

\section{Wpływ gimnastyki leczniczej na obciążanie kończyny dolnej po skręceniu stawu kolanowego na podstawie wybranych testów}

\author{
Jacek Wilczyński, Katarzyna Szaraniec \\ Institute of Physiotherapy, Faculty of Health Sciences, Jan Kochanowski University, Kielce, Poland \\ Head of Institute: Prof. Stanisław Głuszek MD, PhD
}

Key words: knee joint sprain, two-scales test, proprioception, physiotherapy, kinesiotherapy.

Słowa kluczowe: skręcenie stawu kolanowego, test dwóch wag, propriocepcja, fizjoterapia, kinezjoterapia.

\begin{abstract}
Introduction: The issue of knee sprain is increasingly raised in connection with the large number of people that visit rehabilitation centres to recover efficiency and eliminate the pain of an injured joint.

Aim of the research study: To determine the usefulness of medical gymnastics (kinesiotherapy) in the process of limb loading and overcoming the discomfort and pain.

Material and methods: The study included 50 rehabilitated patients of the Rehabilitation Unit of the District Hospital in Staszow, who were troubled with a history of knee sprains. The subjects were selected from 327 patients admitted to the rehabilitation unit within a 3-month period. Two groups of subjects were established (each with 25 people). Evaluation was focused on certain parameters related to the load of the rehabilitated limb, the rate of occurrence of pain felt during standing and walking, and the disappearance of complaints during resting. The group consisted of patients aged 20-64 years, and the median age of those tested was 42 years. The patients came from villages and towns in the county of Staszow, and a significant percentage of them were economically active.

Results: The applied physiotherapy was beneficial as it increased the load on the diseased limbs (two-scales test and standing-on-one-leg test) and improved quality of life, thanks to the palliation of pain to a considerable or complete degree. Conclusions: Physiotherapy enriched with physical exercise allows for faster recovery of an injured leg.
\end{abstract}

\section{Streszczenie}

Wstęp: Problematyka skręcenia stawu kolanowego to coraz powszechniej poruszany temat w związku z liczną grupą osób, która odwiedza punkty rehabilitacyjne w celu odzyskania sprawności i eliminacji doznań bólowych w kontuzjowanym stawie.

Cel pracy: Określenie przydatności gimnastyki leczniczej - kinezyterapii, w procesie obciążania kończyny usprawnianej oraz niwelowania dyskomfortu bólowego.

Materiał i metody: Na Oddziale Rehabilitacji Dziennej Szpitala Powiatowego w Staszowie poddano usprawnianiu 50 pacjentów borykających się z problemami stawu kolanowego po przebytym skręceniu. Badanych wyłoniono spośród 327 pacjentów przyjętych na oddział rehabilitacyjny w ciągu 3 miesięcy. Ustanowiono dwie grupy badanych (po 25 osób). Ocena dotyczyła parametrów związanych z obciążaniem kończyny usprawnianej, z szybkością występowania odczuć bólowych $\mathrm{w}$ trakcie stania i chodzenia, a także z ustępowaniem dolegliwości w bezruchu podczas odpoczynku. Chorzy tworzyli grupę w przedziale wiekowym 20-64 lata, a średni wiek badanych wynosił 42 lata. Pacjenci pochodzili ze wsi i miast powiatu staszowskiego, a znaczny ich odsetek był czynny zawodowo.

Wyniki: Zastosowana fizjoterapia wpłynęła korzystnie na zwiększenie obciążenia chorej kończyny (test dwóch wag i test stania jednonóż) i zwiększenie komfortu życia dzięki uśmierzeniu bólu w stopniu znacznym lub całkowitym.

Wnioski: Fizjoterapia wzbogacona o ćwiczenia fizyczne umożliwia szybszy powrót kontuzjowanej kończyny do sprawności.

\section{Introduction}

The knee joint (articulatio genus) is the largest joint in the human body, and its function in the body continuously exposes it to overload, micro trauma and serious injuries. The complexity of the joint construc- tion obliges rehabilitation, traumatology, orthopaedics and surgery specialists to perform a thorough assessment of the affected joint and provide accurate diagnosis, which is a guarantee of a successful treatment (conservative or operating) [1-3]. 
The knee is a complex joint (hinged modified). It consists of two large bones: the femur and tibia (the fibula does not form part of the knee joint). In the construction of the joint, located centrally and frontally, there is a flat bone: the patella. The joint has two connective menisci matching the articular surfaces to each other during movement. The movements taking place in this joint are bending and straightening movements. In the half-flexion position, there are also slight rotational movements noticed.

The knee is strengthened by external ligaments (lateral tibial, called the collateral medial ligament; and collateral fibular, called the collateral lateral ligament) and internal ligaments (anterior cruciate ligament and the posterior cruciate ligament). The process of stabilisationis also aided by the joint capsule. The knee joint is in the course of a large muscle: the quadriceps muscle of the thigh (quadriceps femoris). Therefore, the joint is exposed to the overload associated with the powerful force of this muscle, which covers with tendon and the front surface of the patella and has its final attachment on the tibial tuberosity (the maximum load of the patella is $300 \mathrm{~kg}$ ). Moreover, as a joint it is second only to the ankle in its load and vulnerability to injury. Pathological mechanisms usually involve the action of powerful rotary forces on the joint, straightening forces or both at once. This can leas to sprains, fractures, twists and bruises. A twisted knee joint loses its stabilizing function as a result of non-physiological stretching of passively stabilising apparatus or mechanical damage (rupture, tear) of the ligaments and joint capsule. Often, as a result of injury, the cushioning function of the joint is lost when the damage covers the meniscus and articular cartilage [4-8].

Physiotherapy after twisting a knee joint is equivalent to conservative treatment and delivers positive health effects. The choice of physiotherapeutic means and methods depends on the extent of the injury, the time elapsed since the traumatic episode and the general health of the patient. In physicotherapy the following are used: ultrasound (UD, UF), laser, liquid nitrogen monoxide/carbon dioxide, IR/UV, magnetic field, galvanic current and two- and four-pole interferential current $[9,10]$. Vibration or classic massage of the quadriceps and gastrocnemius muscle and also lower limb whirlpool are beneficial. Kinesiotherapy is directed to increasing the range of motion in the joint to a generally accepted physiological limit, strengthening the quadriceps of the thigh and pioneering impaired proprioception and balance [11-16].

\section{Aim of the research study}

The aim of this study was to determine the impact of kinesiotherapy on the process of limb loading after knee injury on the basis of the two-scales test and the standing-on-one-leg test. Ongoing research also high- lights the perception of pain in patients with knee sprains, the speed of recovery from pain after the implementation of the various models of physiotherapy and the general quality of life after a serious injury.

\section{Material and methods}

The study involved more than 300 patients from the Daily Rehabilitation Unit SPZZOZ in Staszow within a 3-month period (from December 2010 to March 2011). During this period 50 people were selected from the study group, diagnosed with symptoms indicative of traumatic knee injury as a result of a twisting mechanism. Patients were divided into two numerically equal groups (each with 25 people). Each patient was tested twice: before the start of rehabilitation and after the end of it (after 3 weeks). The first group consisted of the beneficiaries of a comprehensive rehabilitation of concurrent kinesiotherapy and physicotherapy, and the second group was made up of the people subject only to physicotherapy. The groups did not differ significantly by gender. Most of the patients had working status.

The common element of physiotherapeutic treatment in both groups of respondents was physicotherapy. For this purpose the following were used: laser radiation, interference currents, low-frequency magnetic field and local cryotherapy. The exercise program (included in the comprehensive physiotherapy) was implemented only for the second group. Patients chose by themselves and voluntarily which group to join by declaring a willingness to exercise or by giving up medical movement. Kinesiotherapy involved knee extension exercises with sub-maximal load seated, riding a stationary bike with adjustable resistance and individual training that improves the knee joint. Exercise duration, the number of repetitions and load were adapted to the motor capabilities of the individual patient.

This study performed statistical calculations showing the strength of the relationship between the period before and the period after physiotherapy. The basis of the study was a 22-point questionnaire. For questions 1 to 7 and 15 to 18 , responses were given by the injured people; these answers included their personal details, the intensity of pain and membership of the group of people engaged in a full or partial process of rehabilitation treatment. Other points of the survey were based on a general orthopaedic examination in the form of diagnostic tests: the test of standing on just one leg and the two-scales test. Measuring devices such as bathroom scales and a watch with a stopwatch were used.

\section{Results}

In the course of the 3-month research period in the daily unit of Staszow hospital, 15\% of patients were diagnosed with symptoms related to knee joint 
Table 1. The occurrence of pain in the knee injured before and after a partial rehabilitation

\begin{tabular}{|c|c|c|c|c|c|c|c|c|c|c|c|c|c|c|c|c|}
\hline \multirow[t]{4}{*}{ Period } & \multicolumn{16}{|c|}{ Activity } \\
\hline & \multicolumn{8}{|c|}{ Standing } & \multicolumn{8}{|c|}{ Walking } \\
\hline & \multicolumn{2}{|c|}{$10 \mathrm{~min}$} & \multicolumn{2}{|c|}{$30 \mathrm{~min}$} & \multicolumn{2}{|c|}{$1 \mathrm{~h}$} & \multicolumn{2}{|c|}{$2 \mathrm{~h}$} & \multicolumn{2}{|c|}{$5 \mathrm{~min}$} & \multicolumn{2}{|c|}{$15 \mathrm{~min}$} & \multicolumn{2}{|c|}{$30 \mathrm{~min}$} & \multicolumn{2}{|c|}{$1 \mathrm{~h}$} \\
\hline & $n$ & $\%$ & $n$ & $\%$ & $n$ & $\%$ & $n$ & $\%$ & $n$ & $\%$ & $n$ & $\%$ & $n$ & $\%$ & $n$ & $\%$ \\
\hline Before rehabilitation & 3 & 12 & 14 & 56 & 5 & 20 & 3 & 12 & 10 & 40 & 9 & 32 & 5 & 20 & 1 & 4 \\
\hline After rehabilitation & 0 & 0 & 6 & 24 & 12 & 48 & 7 & 28 & 3 & 12 & 6 & 24 & 13 & 52 & 3 & 12 \\
\hline Value $\mathrm{d}_{f}$ & \multicolumn{8}{|c|}{3} & \multicolumn{8}{|c|}{3} \\
\hline $\begin{array}{l}\text { Value } \chi^{2} \\
\text { (for } p=0.05 \text { ) }\end{array}$ & \multicolumn{8}{|c|}{$\begin{array}{l}\text { Empiric: } 9.2 \\
\text { Critical: } 7.81\end{array}$} & \multicolumn{8}{|c|}{$\begin{array}{l}\text { Empiric: } 8.9 \\
\text { Critical: } 7.81\end{array}$} \\
\hline$r_{c}$ & \multicolumn{8}{|c|}{0.4} & \multicolumn{8}{|c|}{0.4} \\
\hline Relationship strenght & \multicolumn{8}{|c|}{ Average } & \multicolumn{8}{|c|}{ Average } \\
\hline
\end{tabular}

Resource: own research

sprain. The subjects were divided into two groups: 25 patients were treated with physicotherapy (partial rehabilitation) and 25 patients with physicotherapy and kinesiotherapy (complex rehabilitation).

Prior to partial rehabilitation of the knee joint after joint twisting, the painless standing period in 3 patients (12\%) was $10 \mathrm{~min}$, in 14 patients $(56 \%)$ it was $30 \mathrm{~min}$, in 5 patients (20\%) it was $1 \mathrm{~h}$ and in 3 patients $(12 \%)$ it was $2 \mathrm{~h}$. After partial improvement the appearance of pain was delayed. In 6 cases (24\%) unpleasant symptoms occurred after $30 \mathrm{~min}$, in 12 patients (48\%) this occurred after $1 \mathrm{~h}$ and in 7 patients $(28 \%)$ it was after $2 \mathrm{~h}$. After partial rehabilitation of the twisted joint the number of people standing in two maximum dimensions of time ( $1 \mathrm{~h}, 2 \mathrm{~h})$ more than doubled compared to the period before rehabilitation (Table 1, Figure 1).

Prior to partial physiotherapy, 10 patients (40\%) experienced pain after 5 min of walking, 9 patients (36\%) after $15 \mathrm{~min}, 5$ patients (20\%) after $30 \mathrm{~min}$ and 1 person (4\%) after $1 \mathrm{~h}$. After partial rehabilitation, patients showed the ability to walk for longer than before the treatment. Three of the subjects (12\%) could walk for only up to $5 \mathrm{~min}$. Six patients (24\%) could walk without pain for up to $15 \mathrm{~min}, 13$ patients (52\%) up to $30 \mathrm{~min}$, and 3 patients (12\%) to about $1 \mathrm{~h}$. As in the case of standing, the number of patients in the two longest dimensions of time (30 min, $1 \mathrm{~h}$ ) successively doubled and tripled compared to the period before physiotherapy (Table 1, Figure 1). The dependence of standing or walking time without feeling pain on the partial improvement is significant and the correlation moderate $\left(\chi^{2}=9.2\right.$ for standing and $\chi^{2}=8.9$ for walking; $r_{c} \approx 0.4 ; d_{f}=3$ ).

Before comprehensive improvement of the injured knee joint the period of standing without pain was $10 \mathrm{~min}$ in 3 patients (12\%), $30 \mathrm{~min}$ in 10 patients (40\%), $1 \mathrm{~h}$ in 9 patients (36\%) and $2 \mathrm{~h}$ in 3 patients (12\%). After complex improvement the time until onset of pain was extended. In 5 persons (20\%) unpleasant symptoms occurred after $30 \mathrm{~min}$, in 6 patients (24\%) after

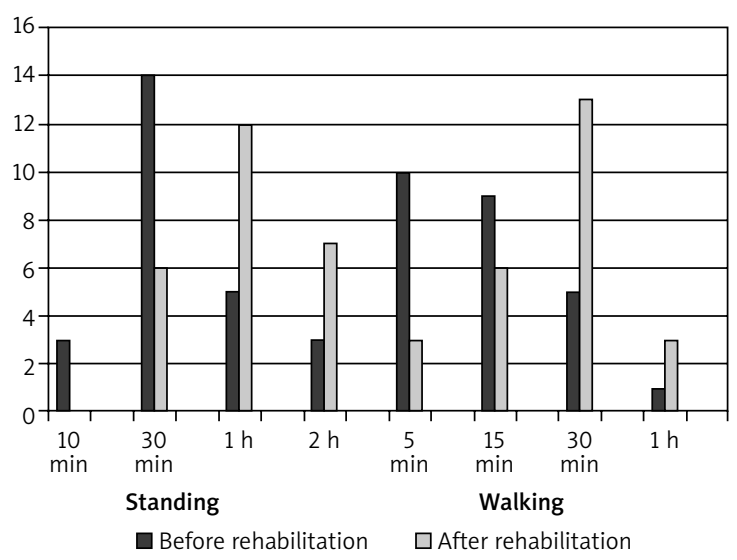

Figure 1. The occurrence of pain in the knee when standing and walking in the period before and after partial physiotherapy

$1 \mathrm{~h}$ and in as many as 14 patients (56\%) this occurred after $2 \mathrm{~h}$. After complex rehabilitation of the twisted joint the number of persons able to stand for a given period of time $(2 \mathrm{~h})$ increased almost 5 -fold compared to the results prior to physiotherapy (Table 2, Figure 2).

Prior to complex physiotherapy, 5 patients (20\%) experienced pain while walking after $5 \mathrm{~min}, 7$ patients (28\%) after $15 \mathrm{~min}, 10$ patients (40\%) after $30 \mathrm{~min}$ and 3 persons (12\%) after $1 \mathrm{~h}$. After improvement with the use of physicotherapy and kinesiotherapy the patients showed a longer period of walking than before rehabilitation. Four subjects (16\%) moved up to $15 \mathrm{~min}, 8$ patients (32\%) reached awalking time without pain of up to $30 \mathrm{~min}$, and 13 patients (52\%) could walk for up to $1 \mathrm{~h}$. The number of patients able to walkfor the longest period $(1 \mathrm{~h})$ increased more than 4 -fold relative to the period prior to physiotherapy (Table 2, Figure 2). The dependence of standing and walking time without feeling pain on the comprehensive improvement is significant, and the correlation is moderate $\left(\chi^{2}=10.88\right.$ for standing and $\chi^{2}=9.8$ for walking; $r_{c} \approx 0.4 ; d_{f}=3$ ). 
Table 2. The occurrence of pain in the injured knee before and after complex rehabilitation

\begin{tabular}{|c|c|c|c|c|c|c|c|c|c|c|c|c|c|c|c|c|}
\hline \multirow[t]{4}{*}{ Period } & \multicolumn{16}{|c|}{ Activity } \\
\hline & \multicolumn{8}{|c|}{ Standing } & \multicolumn{8}{|c|}{ Walking } \\
\hline & \multicolumn{2}{|c|}{$10 \mathrm{~min}$} & \multicolumn{2}{|c|}{$30 \mathrm{~min}$} & \multicolumn{2}{|c|}{$1 \mathrm{~h}$} & \multicolumn{2}{|c|}{$2 \mathrm{~h}$} & \multicolumn{2}{|c|}{$5 \mathrm{~min}$} & \multicolumn{2}{|c|}{$15 \mathrm{~min}$} & \multicolumn{2}{|c|}{$30 \mathrm{~min}$} & \multicolumn{2}{|c|}{$1 \mathrm{~h}$} \\
\hline & $n$ & $\%$ & $n$ & $\%$ & $n$ & $\%$ & $n$ & $\%$ & $n$ & $\%$ & $n$ & $\%$ & $n$ & $\%$ & $n$ & $\%$ \\
\hline Before rehabilitation & 3 & 12 & 10 & 40 & 9 & 36 & 3 & 12 & 5 & 20 & 7 & 28 & 10 & 40 & 3 & 12 \\
\hline After rehabilitation & 0 & 0 & 5 & 20 & 6 & 24 & 14 & 56 & 0 & 0 & 4 & 16 & 8 & 32 & 13 & 52 \\
\hline Value $\mathrm{d}_{f}$ & \multicolumn{8}{|c|}{3} & \multicolumn{8}{|c|}{3} \\
\hline Value $\chi^{2}($ for $p=0.05)$ & \multicolumn{8}{|c|}{$\begin{array}{c}\text { Empiric: } 10.88 \\
\text { Critical: } 7.81\end{array}$} & \multicolumn{8}{|c|}{$\begin{array}{l}\text { Empiric: } 9.8 \\
\text { Critical: } 7.81\end{array}$} \\
\hline$r_{c}$ & \multicolumn{8}{|c|}{0.4} & \multicolumn{8}{|c|}{0.4} \\
\hline Relationship strenght & \multicolumn{8}{|c|}{ Average } & \multicolumn{8}{|c|}{ Average } \\
\hline
\end{tabular}

Resource: own research

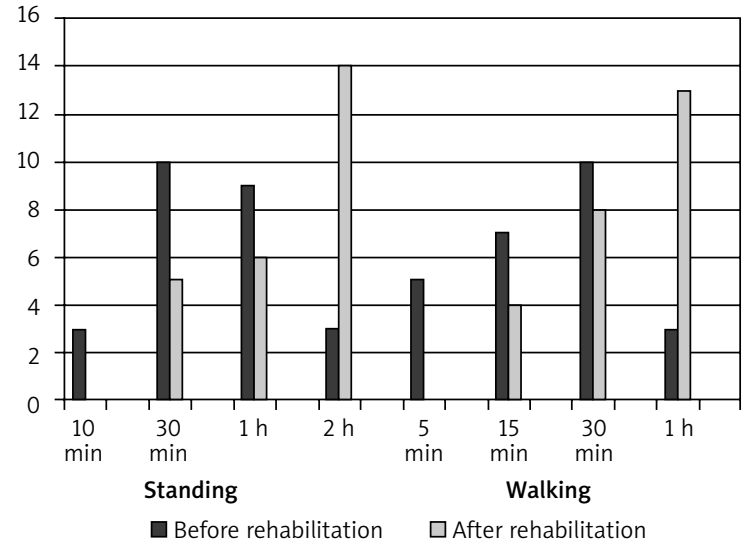

Figure 2. The occurrence of pain in the knee when standing and walking in the period before and after comprehensive rehabilitation

Prior to daily hospital physiotherapy, pain in the knee disappeared after resting for 5 min in 5 patients (20\%), 15 min in 16 patients (64\%), $30 \mathrm{~min}$ in 3 patients (12\%) and after $1 \mathrm{~h}$ in 1 patient (4\%). After partial physiotherapy of the twisted knee, the minimum rest period (5 min) after which the pain was not felt was recorded in 9 patients (36\%). Fourteen patients $(56 \%)$ required $15 \mathrm{~min}$ of rest in order to reduce pain, and 2 people $(8 \%)$ required $30 \mathrm{~min}$. The number of respondents who did not feel knee pain after $5 \mathrm{~min}$ of rest almost doubled after the use of physical treatments compared to the number before the therapy (Table 3, Figure 3). The correlation between the rate of disappearance of knee pain and partial improvement is poor, and the relationship has almost no significance $\left(\chi^{2}=2 ; r_{c} \approx 0.2 ; \mathrm{d}_{f}=3\right)$.

Prior to hospital physiotherapy, pain in the knee subsided after resting for $5 \mathrm{~min}$ in 5 patients (20\%), after $15 \mathrm{~min}$ in 10 patients (40\%), after $30 \mathrm{~min}$ in 9 patients (36\%) and after $1 \mathrm{~h}$ in 1 patient (4\%). Following comprehensive improvement of the twisted joint, the number of people showing painlessness after resting for $5 \mathrm{~min}$ increased to 13 patients (52\%). Eleven patients $(44 \%)$ required $15 \mathrm{~min}$ of rest in order to relieve pain and 1 person $(4 \%)$ required $30 \mathrm{~min}$. The number of patients who did not feel knee pain after $5 \mathrm{~min}$ of rest increased by a factor of more than 2.5 after the application of comprehensive treatment (Table 4, Figure 4). The correlation between the rate of recovery from knee pain and complex improvement is moderate and the dependence is significant $\left(\chi^{2}=10.5 ; r_{c} \approx 0.4\right.$; $\left.d_{f}=3\right)$.

The results of the test of standing on one leg for $1 \mathrm{~min}$, before the implementation of physical treatment for injured limbs, was positive only in the case of 3 patients (12\%), i.e. these 3 patients were able to stand on the injured leg for a time equal to or longer than $60 \mathrm{~s}$. After partial rehabilitation of the injured knee joint, the number of patients increased to 13 patients (52\%), a more than 4 -fold increase. Thus, the number of people prior to physiotherapy with a time of standing on the injured leg less than $1 \mathrm{~min}$. Decreased by a factor of almost 2 [before rehabilitation -22 people (88\%), after rehabilitation -12 people $(48 \%)$ ] (Table 5 , Figure 5). The relationship between time of standing on one leg (on the injured limb) and partial rehabilitation is significant and the correlation is moderate $\left(\chi^{2}=14.6 ; r_{c} \approx 0.5 ; d_{f}=1\right)$.

The result of the test of standing with one leg for $1 \mathrm{~min}$, before complex physiotherapy of the injured knee joint, was positive in 2 patients (8\%). After medical improvement of the injured joint the number of patients increased to 16 (64\%), i.e. an 8-fold increase. The number of patients who achieved a negative result before physiotherapy (the time of standing on the injured leg was shorter than $1 \mathrm{~min}$ ) was as high as 23 (92\%). After conservative treatment, the number dropped two and a half time and it was 9 patients (36\%) (Table 6, Figure 6). The relationship between the time of standing on one leg (on the injured limb) and the complex rehabilitation is significant and the correlation is moderate $\left(\chi^{2}=17 ; r_{c} \approx 0.5 ; d_{f}=1\right)$. 
Table 3. The rate of disappearance of pain in the knee joint before and after partial rehabilitation

\begin{tabular}{|c|c|c|c|c|c|c|c|c|}
\hline \multirow[t]{3}{*}{ Period } & \multicolumn{8}{|c|}{ Disappearance of pain after rest } \\
\hline & \multicolumn{2}{|c|}{$5 \mathrm{~min}$} & \multicolumn{2}{|c|}{$15 \mathrm{~min}$} & \multicolumn{2}{|c|}{$30 \mathrm{~min}$} & \multicolumn{2}{|c|}{$1 \mathrm{~h}$} \\
\hline & $n$ & $\%$ & $n$ & $\%$ & $n$ & $\%$ & $n$ & $\%$ \\
\hline Before rehabilitation & 5 & 20 & 16 & 64 & 3 & 12 & 1 & 4 \\
\hline After rehabilitation & 9 & 36 & 14 & 56 & 2 & 8 & 0 & 0 \\
\hline Value $\mathrm{d}_{f}$ & \multicolumn{8}{|c|}{3} \\
\hline Value $\chi^{2}($ for $p=0.05)$ & \multicolumn{8}{|c|}{$\begin{array}{l}\text { Empiric: } 2 \\
\text { Critical: } 7.81\end{array}$} \\
\hline$r_{c}$ & \multicolumn{8}{|c|}{0.2} \\
\hline Relationship strenght & \multicolumn{8}{|c|}{ Poor } \\
\hline
\end{tabular}

Resource: own research

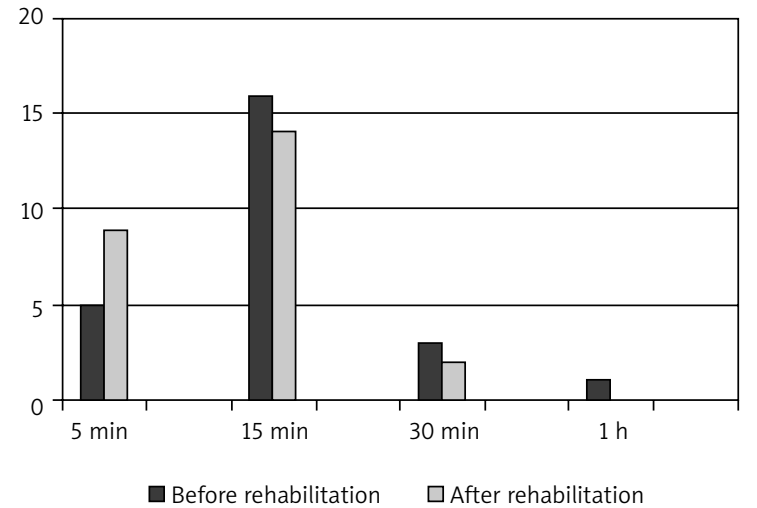

Figure 3. The rate of disappearance of pain in the knee joint before and after partial physiotherapy

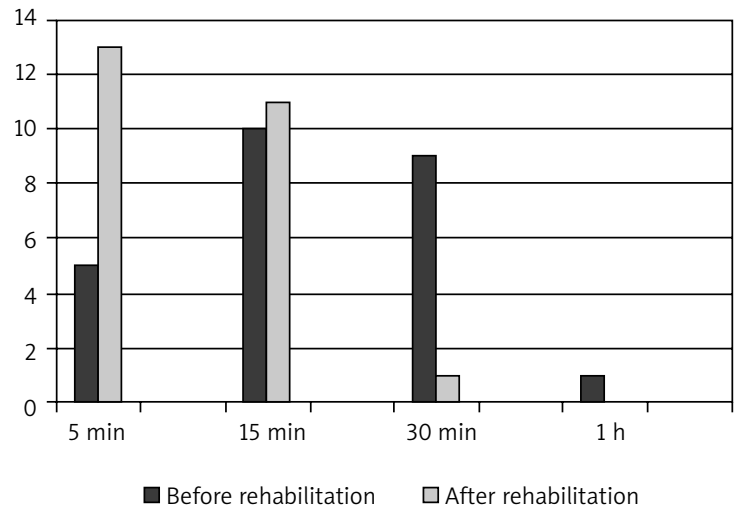

Figure 4. The rate of disappearance of pain in the knee joint before and after complex physiotherapy

Table 4. The rate of disappearance of pain in the knee joint before and after complex rehabilitation

\begin{tabular}{|c|c|c|c|c|c|c|c|c|}
\hline \multirow[t]{3}{*}{ Period } & \multicolumn{8}{|c|}{ Disapperance of pain after rest } \\
\hline & \multicolumn{2}{|c|}{$5 \mathrm{~min}$} & \multicolumn{2}{|c|}{$15 \min$} & \multicolumn{2}{|c|}{$30 \mathrm{~min}$} & \multicolumn{2}{|c|}{$1 \mathrm{~h}$} \\
\hline & $n$ & $\%$ & $n$ & $\%$ & $n$ & $\%$ & $n$ & $\%$ \\
\hline Before rehabilitation & 5 & 20 & 10 & 40 & 9 & 36 & 1 & 4 \\
\hline After rehabilitation & 13 & 52 & 11 & 44 & 1 & 4 & 0 & 0 \\
\hline Value $\mathrm{d}_{f}$ & \multicolumn{8}{|c|}{3} \\
\hline Value $\chi^{2}$ (for $\left.p=0.05\right)$ & \multicolumn{8}{|c|}{$\begin{array}{l}\text { Empiric: } 10.5 \\
\text { Critical: } 7.81\end{array}$} \\
\hline$r_{c}$ & \multicolumn{8}{|c|}{0.4} \\
\hline Relationship strenght & \multicolumn{8}{|c|}{ Average } \\
\hline
\end{tabular}

Resource: own research

The two-scales test was used to demonstrate the unequal load of lower limbs, predominantly carrying the weight of the body on a healthy leg, usually in order to alleviate load on an injured limb.

The values given in Table 7 were calculated by reducing the measurement of the load of an injured lower limb after rehabilitation by the measurement of that limb before physiotherapy. Then the figures were classified into three ranges. After a partial im- provement 7 patients (28\%) did not change the weight distribution of the body relative to the period before physiotherapy, and after complex improvement there were $3(12 \%)$ such patients. An increase in load of the injured limb by $1-5 \mathrm{~kg}$ was recorded in 14 patients (56\%) partially involved in the physiotherapy and in 15 patients $(60 \%)$ involved fully. After completing partial physiotherapy, an increase in load on the injured limb of 6-10 kg occurred in 4 patients (16\%) and 
Table 5. Test of standing on one leg before and after partial physiotherapy

\begin{tabular}{|c|c|c|c|c|}
\hline \multirow[t]{3}{*}{ Period } & \multicolumn{4}{|c|}{ Standing on the injured leg } \\
\hline & \multicolumn{2}{|c|}{$<1 \min$} & \multicolumn{2}{|c|}{$>1 \mathrm{~min}$} \\
\hline & $n$ & $\%$ & $n$ & $\%$ \\
\hline Before rehabilitation & 22 & 88 & 3 & 12 \\
\hline After rehabilitation & 12 & 48 & 13 & 52 \\
\hline Value $d_{f}$ & \multicolumn{4}{|c|}{1} \\
\hline Value $\chi^{2}$ (for $p=0.05$ ) & \multicolumn{4}{|c|}{$\begin{array}{l}\text { Empiric: } 14.6 \\
\text { Critical: } 3.84\end{array}$} \\
\hline$r_{c}$ & \multicolumn{4}{|c|}{0.5} \\
\hline Relationship strenght & \multicolumn{4}{|c|}{ Average } \\
\hline
\end{tabular}

Resource: own research

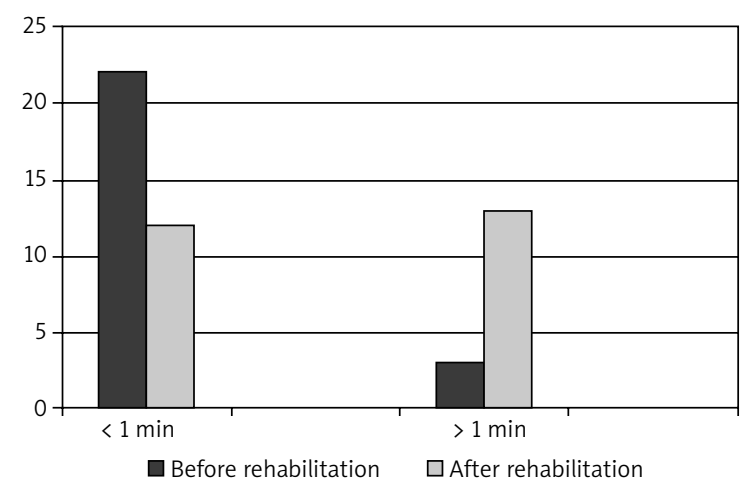

Figure 5. Test of standing on one leg before and after partial physiotherapy

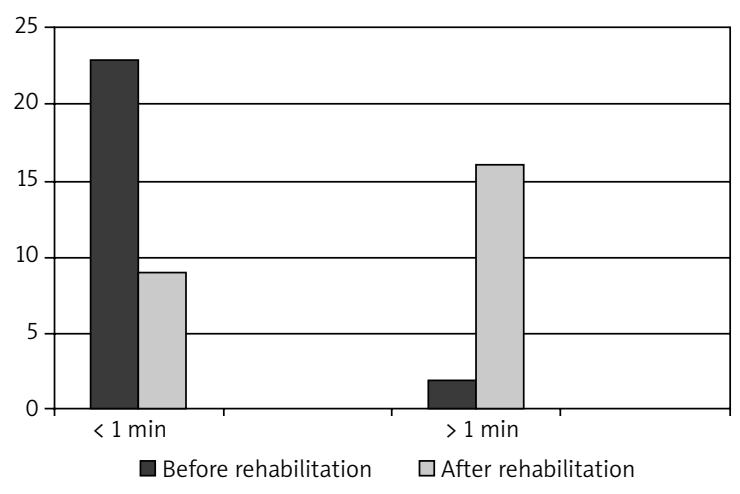

Figure 6. Test of standing on one leg before and after complex physiotherapy

Table 6. Test of standing on one leg before and after complex physiotherapy

\begin{tabular}{|c|c|c|c|c|}
\hline \multirow[t]{3}{*}{ Period } & \multicolumn{4}{|c|}{ Standing on the injured leg } \\
\hline & \multicolumn{2}{|c|}{$<1 \mathrm{~min}$} & \multicolumn{2}{|c|}{$>1 \mathrm{~min}$} \\
\hline & $n$ & $\%$ & $n$ & $\%$ \\
\hline Before rehabilitation & 23 & 92 & 2 & 8 \\
\hline After rehabilitation & 9 & 36 & 16 & 64 \\
\hline Value $\mathrm{d}_{f}$ & \multicolumn{4}{|c|}{1} \\
\hline Value $\chi^{2}$ (for $\left.p=0.05\right)$ & \multicolumn{4}{|c|}{$\begin{array}{c}\text { Empiric: } 17 \\
\text { Critical: } 3.84\end{array}$} \\
\hline$r_{c}$ & \multicolumn{4}{|c|}{0.5} \\
\hline Relationship strenght & \multicolumn{4}{|c|}{ Average } \\
\hline
\end{tabular}

Resource: own research

after complex treatment - in 7 patients (28\%) (Table 7, Figure 7). The relationship between increase in load of the injured leg and the type of rehabilitation is well established, but small, and the correlation is low $\left(\chi^{2}=2.5 ; r_{c} \approx 0.2 ; d_{f}=2\right)$.

\section{Discussion}

In light of the research and our own clinical experience, knee sprains are a major health problem in all age groups. After a history of knee injury physically active young people are forced to temporarily or completely cease practicing in competitive sports, restrict strenuous exercise and change their lifestyle to a safer one. In terms of occupation, knee injuries can affect the increased absence from work, which is a social and economic problem. Among retirees/pensioners the occurrence of a knee injury significantly affects quality of life by causing an inability to cope with daily activities and forcing a dependence on others. From a psychological point of view, depressed mood and 
Table 7. Test of the two scales after partial and complex rehabilitation

\begin{tabular}{|c|c|c|c|c|c|c|}
\hline \multirow[t]{3}{*}{ Period } & \multicolumn{6}{|c|}{ Increase on the injured leg load } \\
\hline & \multicolumn{2}{|c|}{ Lack } & \multicolumn{2}{|c|}{$1-5 \mathrm{~kg}$} & \multicolumn{2}{|c|}{$6-10 \mathrm{~kg}$} \\
\hline & $n$ & $\%$ & $n$ & $\%$ & $n$ & $\%$ \\
\hline After partial rehabilitation & 7 & 28 & 14 & 56 & 4 & 16 \\
\hline After complex rehabilitation & 3 & 12 & 15 & 60 & 7 & 28 \\
\hline Value $\mathrm{d}_{f}$ & \multicolumn{6}{|c|}{2} \\
\hline Value $\chi^{2}$ (for $p=0.05$ ) & \multicolumn{6}{|c|}{$\begin{array}{l}\text { Empiric: } 2.5 \\
\text { Critical: } 5.99\end{array}$} \\
\hline$r_{c}$ & \multicolumn{6}{|c|}{0.2} \\
\hline Relationship strenght & \multicolumn{6}{|c|}{ Poor } \\
\hline
\end{tabular}

Resource: own research

even symptoms of depression and anxiety disorders may afflict, to a greater or lesser extent, those affected by traumatic knee dysfunction. Properly performed physiotherapy reduces the time to return to pre-injury physical fitness, which has a positive effect on the psyche of the patient.

The physiotherapeutic process for light joint sprains is fast and efficient (according to the RICE rule: rest, cold compresses/cryotherapy, band/stabilising pressure bandage, elevation of the limb) and treatment is usually in the patient's home. Sprains running with partial or total damage to intra-articular structures, i.e. moderate or severe, require a long-term rehabilitation process based on diagnostic and/or reconstructive arthroscopy and a program of conservative treatment (for as long as 12 months) [17, 18].

One of the main points of physiotherapy is the analgesic action on the twisted knee joint. The reduction or relief of pain has a significant impact on quality of life and the progress of rehabilitation. Studies have shown more effective rehabilitation from programs enriched with kinesiotherapy in the delayed occurrence and elimination of pain that occurred after prolonged standing and walking. Motor exercises help to restore the normal model of walking that was previously compromised by the unequal burdening the lower limbs. Poor distribution of forces on the various joints of the lower limbs is due to the fear of pain, aggravation of knee pathology and falling. Daily kinesiotherapy by strengthening the relevant muscles, proprioception pioneering and shaping the static and dynamic balance influences the patient's growth of confidence in the possibility of compensating their body, reduces anxiety and, very importantly, preserves the correct model of movement (which in the future will reduce the over - exploitation of other joints of the lower limb) [19].

\section{Conclusions}

Paving the proprioception of the knee joint is an important factor for improving overall efficiency in patients after twisting the joint. The obtained results

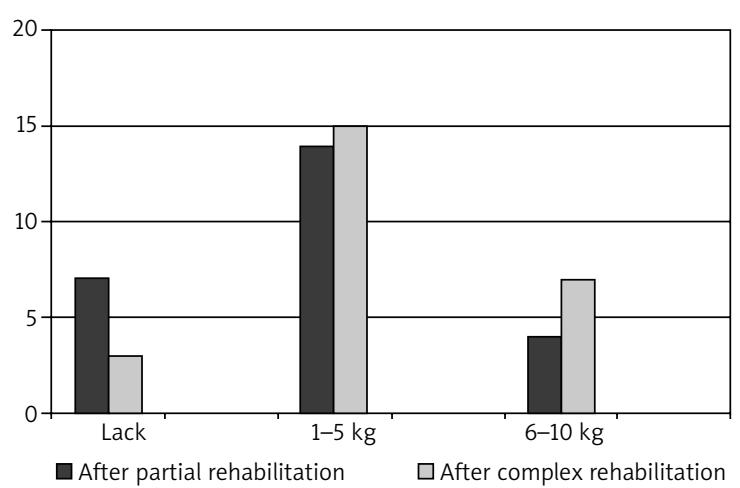

Figure 7. The increase in load on the injured leg after application of physiotherapy

of improvement showed that the model of complex rehabilitation enables a faster return to normal efficiency of the injured leg. The elimination of pain in the injured lower limb significantly improves daily physical activity.

\section{References}

1. Uszkodzenia stawu kolanowego. Górecki A (ed). PZWL, Warsaw 1997.

2. Stawy rzepkowo-udowe: wybrane problemy patologii, diagnostyki i terapii: opracowanie zbiorowe. Modrzewski K (ed). BiFolium, Lublin 1998.

3. Sokołowska-Pituchowa J. Anatomia człowieka: podręcznik dla studentów medycyny. PZWL, Warsaw 2006.

4. Dziak A, Tayara S. Urazy i uszkodzenia w sporcie. Kasper, Krakow 2009.

5. Uszkodzenia chrząstki kolana. Górecki A, Kuś WM (eds.). Oficyna Wydawniczo-Poligraficzna „Adam”, Warsaw 2010.

6. Widuchowski J. Kolano: artroskopia diagnostyczna i operacyjna. Sport Med, Katowice 2002.

7. Logerstedt DS, Snyder-Mackler L, Ritter RC, et al. Knee stability and movement coordination impairments: knee ligament sprain. Orthopaedic Section of the American Physical Therapist Association. J Orthop Sports Phys Ther 2010; 40: A1-A37.

8. Beaulieu MJ. Overtraining in the young athlete: an increase in anterior cruciate ligament and meniscal injuries. Perspect Infirm 2012; 9: 43. 
9. Bojek W. Krioterapia - uwagi ogólne. Balneologia Polska 2006; 1: 64-67.

10. Szlachta M, Polak A, Błaszczyk B, et al. Badanie skuteczności ultradźwięków i elektrofonoforezy we wspomaganiu leczenia choroby zwyrodnieniowej stawu kolanowego. FP 2009; 9: 211-222.

11. Escamilla RF. Knee biomechanics of the dynamic squat exercise. Med Sci Sports Exerc 2001; 33: 127-141.

12. Hewett TE, Lindenfeld TN, Riccobene JV, et al. The effect of neuromuscular training on the incidence of knee injury in female athletes. Am J Sports Med 1999; 27: 699-706.

13. Mizner RL, Petterson SC, Snyder-Mackler L. Quadriceps strength and the time course of functional recovery after total knee arthroplasty. J Orthop Sports Phys Ther 2005 35: 424-436.

14. Mascarin NC, Vancini RL, Andrade ML, et al. Effects of kinesiotherapy, ultrasound and electrotherapy in management of bilateral knee osteoarthritis: prospective clinical trial. BMC Musculoskelet Disord 2012; 13: 182.

15. Deyle GD, Henderson NE, Matekel RL, et al. Effectiveness of manual physical therapy and exercise in osteoarthritis of the knee. Ann Intern Med 2000; 132: 173-181.

16. Jansen MJ, Viechtbauer W, Lenssen AF, et al. Strength training alone, exercise therapy alone, and exercise therapy with passive manual mobilisation each reduce pain and disability in people with knee osteoarthritis: a systematic review. J Physiother 2011; 57: 11-20.

17. Wilk M, Trąbka R, Tomaszewski W. Wstępne wyniki zastosowania protokołu rehabilitacyjnego we wczesnym okresie u pacjentów po artroskopowej przezportalowej jedno i dwupęczkowej rekonstrukcji więzadła krzyżowego przedniego z użyciem ścięgien mięśni półścięgnistego i smukłego. FP 2009; 9: 97-103.

18. Ardern CL, Taylor NF, Feller JA, et al. Psychological responses matter in returning to preinjury level of sport after anterior cruciate ligament reconstruction surgery. Am J Sports Med 2013; 41: 1549-1558.

19. Wierike SC, van der Sluis A, van den Akker-Scheek I, et al. Psychosocial factors influencing the recovery of athletes with anterior cruciate ligament injury: a systematic review. Scand J Med Sci Sports 2013; 23: 527-540.

\section{Address for correspondence:}

Jacek Wilczyński PhD, Prof. UJK

Department of Neurology, Neurological Rehabilitation

and Kinesitherapy

Institute of Physiotherapy

Faculty of Health Sciences

Jan Kochanowski University

al. IX Wieków Kielc 19, 25-317 Kielce, Poland

Phone: +48603703926

E-mail: jwilczynski@onet.pl 